DEMOGRAPHIC RESEARCH

VOLUME 29, ARTICLE 29, PAGES 797-816

PUBLISHED 11 OCTOBER 2013

http://www.demographic-research.org/Volumes/Vol29/29/

DOI: $10.4054 /$ DemRes.2013.29.29

Research Article

Effects of parental union dissolution on child mortality and schooling in Burkina Faso

Bilampoa Gnoumou Thiombiano

Thomas K. LeGrand

Jean-François Kobiané

๑2 2013 Gnoumou Thiombiano, LeGrand \& Kobiané.

This open-access work is published under the terms of the Creative Commons Attribution NonCommercial License 2.0 Germany, which permits use, reproduction \& distribution in any medium for non-commercial purposes, provided the original author(s) and source are given credit. See http:// creativecommons.org/licenses/by-nc/2.0/de/ 


\section{Table of Contents}

$\begin{array}{lll}1 & \text { Introduction } & 798\end{array}$

$2 \quad$ Data and method $\quad 799$

$\begin{array}{lll}2.1 & \text { Data } & 799\end{array}$

$2.2 \quad$ Method and variables $\quad 800$

2.3 Limitations of the data 802

3 Results $\quad 803$

$\begin{array}{lll}3.1 & \text { Descriptive analysis } & 803\end{array}$

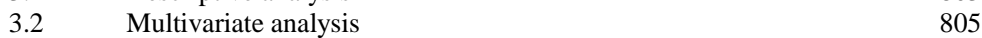

4 Discussion $\quad 809$

$\begin{array}{ll}\text { References } & 811\end{array}$

$\begin{array}{ll}\text { Appendix } & 815\end{array}$ 


\title{
Effects of parental union dissolution on child mortality and schooling in Burkina Faso
}

\author{
Bilampoa Gnoumou Thiombiano ${ }^{1}$ \\ Thomas K. LeGrand ${ }^{2}$ \\ Jean-François Kobiané $e^{3}$
}

\begin{abstract}

\section{BACKGROUND}

Family structure and union dissolution has been one of the most thoroughly studied determinants of children's wellbeing worldwide. To date, however, few of these studies have examined sub-Saharan Africa, especially countries in West Africa where marital breakdowns are not uncommon.
\end{abstract}

\section{OBJECTIVE}

We attempt to examine the effects of a mother's divorce and widowhood on children's risk of mortality under age 5 and on their probability of entering primary school.

\section{METHODS}

Survival data analysis methods, specifically Kaplan-Meier and piecewise exponential models, are used for analysis, based on data come from the 2000 Migration and Urban Integration Survey of Burkina Faso.

\section{RESULTS}

Compared to those of intact families, children of divorced parents experience higher estimated mortality risks under age 5 and a lower probability of entering school, even after controlling for various other factors. This effect is large and significant during the first two years after the divorce. The death of the father is also found to greatly reduce a child's likelihood of entering school, but its effect on mortality is not significant.

1 Higher Institute of Population Sciences (ISSP), University of Ouagadougou, Burkina Faso. E-mail: bgnoumou@issp.bf.

${ }^{2}$ Université de Montréal, Canada.

${ }^{3}$ University of Ouagadougou, Burkina Faso. 


\section{CONCLUSION}

The results indicate that the family context plays an important role in determining two important aspects of children's welfare: their probabilities of dying before age 5 and of entering school.

\section{COMMENTS}

Children of divorced parents or a deceased father are living in precarious situations and their specific needs should be taken into account in policies in order to improve the wellbeing of all children. Attention must be directed to the first two years following the union dissolution.

\section{Introduction}

Studies in many countries show that family structure plays a key role in the wellbeing of children. For instance, mortality has been found to be higher for children born out of wedlock (Bennett et al. 1994; Isaac and Feinberg 1982), those in polygamous households (Foster 2002) ${ }^{4}$, and those whose parents are divorced (Alam et al. 2001; Mauldon 1990; Bhuiya and Chowdhury 1997). Family structure may also affect other dimensions of child welfare. Across sub-Saharan Africa, female-headed households appear to be more successful at schooling their children than those headed by a man (Lloyd and Blanc 1996) ${ }^{5}$. Research has also indicated that orphans are less likely to attend school than are non-orphans (Ainsworth and Filmer 2002; Kobiané et al. 2005).

Though family structure and union dissolution has been one of the most thoroughly studied determinants of children's wellbeing worldwide, only a few studies have analyzed this issue in sub-Saharan Africa. Whereas marital breakdowns are not uncommon in the region, especially in West Africa (Lesthaeghe et al. 1989), the effect of marital dissolution on children's welfare -their survival and schooling- has rarely been examined. Part of this gap in research reflects a lack of adequate data. In censuses and surveys, information on individuals' marital status is often provided only in relation to current unions, making it impossible to examine children's life histories in relation to changes in their mothers' marital status.

\footnotetext{
${ }^{4}$ This finding is not consistent across studies (e.g., Sear et al. 2002).

${ }^{5}$ Yet the status of female head encompasses a wide range of physical and social realities. In addition to divorced, widowed and single women, this group can include currently married women who were not cohabiting with their husbands at the time of the survey, which may be occasioned by a husband's labour migration or polygamy without co-residence. In the latter case, the husband often actively participates in childcare, especially with regard to healthcare and education. In contrast, divorced and widowed women may often be the main or sole providers for the needs of their children.
} 
This paper uses retrospective family life history data from a survey fielded in Burkina Faso to examine the effects of union dissolution on child survival and entry into school. Following Lloyd and Blanc (1996), we expect that children reared by married parents will have better health and educational outcomes (Lloyd and Blanc 1996). Parental union breakup is expected to be a traumatic event in a child's life and to reduce the care and resources s/he receives, due to the absence of a parent. We hypothesize that children whose parents are divorced or widowed will be at a greater risk of dying before age 5 and less likely to enter school than those living with both parents. Whilst children's overall wellbeing (including their survival and education) might theoretically increase the risk of parents' divorce, we assume that such effect is negligible in a context of large family sizes, polygamous unions and extended kin networks like Burkina Faso.

In the following section, we describe the data and methods used in this study. We then present the results of the descriptive and multivariate analyses before discussing the study's results and implications.

\section{Data and method}

\subsection{Data}

Data are from the Migration and Urban Integration Survey of Burkina Faso (MUIS/BF), conducted in 2000 by the Higher Institute of Population Sciences (ISSP) of the University of Ouagadougou (Burkina Faso), the Demography Department of the University of Montreal, and the Center for Research and Studies in Population (CERPOD) in Mali. This survey provides detailed retrospective data from 4,258 households and 4,685 women aged 15 to 64 at the time of the survey. Using the event history calendar method, information was collected on the marital, migratory, and reproductive histories of these women (see Poirier et al. 2001 for details). Our analysis of child mortality and schooling is based mainly on the data on the reproductive and marital histories. Altogether, reproductive history data concerned 17,544 children. The sample used for this study covered 17,399 children whose mothers had ever been married. Of them, 2,763 children died under age 5, and only 4,902 children were enrolled in school between the ages of 5 and 10. For each child, interviewers recorded information on the date of birth, birth order, gender and, for deceased children, the date of death. The date of first school enrollment was also recorded for those who had ever been to school. The marital history module of the questionnaire provides information about each woman's union: dates of first cohabitation and wedding ceremonies (civil, 
religious, and traditional), and date of union dissolution, if any. The dates of all of these events were given in month and year.

As a retrospective survey, the MUIS/BF is well suited to our analytical needs. In contrast to data from censuses and most other surveys, it provides event history data that indicates, for example, the mother's marital status at the time of her child's first enrollment in school, or death. The use of event-history calendars is known to improve accuracy in the collection of retrospective data, including on past events such as weddings, divorces, school enrollment and deaths (Freedman et al. 1988; Panel Study of Income Dynamics 2012).

\subsection{Method and variables}

Survival data analysis methods - Kaplan-Meier graphs for the descriptive analysis and piecewise exponential models for the multivariate analysis - are used to examine the impact over time of the occurrence of an event, such as father's death, on children's survival or entry into school (Blossfeld and Rohwer 2002). The piecewise exponential model was chosen for this study because of its flexibility. This parametric model makes it possible to segment the risk function into specific time intervals, and thus take into account the changing mortality risks, and the probability of starting school, over time and age (Blossfeld et al. 2007; Blossfeld and Rohwer 2002). The time intervals used for the analysis of mortality risk were [0-1) month, [1-11] months, and [12-59] months; for school entry, the cut-off ages were under age 7, ages 7 or 8 , and 8 to 10 years. In Burkina Faso, the official age of school entry is $7^{6}$, but this is not generally respected. Children's first school enrollment can vary between the ages of 5 and 10 years, and many begin school between the ages of 7 and 8 . As a fully parametric model, the piecewise exponential approach provides an estimate of the baseline risk for each of the age-time intervals listed above. Sample weights are used in both the descriptive and multivariate analyses, and robust standard error estimates are used to handle heteroscedasticity and auto-correlated disturbances that occur when more than one child in the sample was born to the same mother.

The two dependent variables are death under age 5 for the analysis of child mortality, and entry into school for the analysis of schooling. These are coded "1" in the event of death or entry into school for each child and "0" otherwise. Duration time until event occurrence is measured by the age of the child. The main independent variable is the marital status of the mother. On the assumption that the effect of marital dissolution on child mortality and entry into school may change over time, we subdivided the

\footnotetext{
${ }^{6}$ At the time of the survey official age of school entry was 7. But since the academic year 2007-2008, official age is 6 .
} 
divorced and widowed categories by time since the event: less than two years, and two years or more. The married category includes all married women whatever the duration of marriage. A number of bio-demographic, socioeconomic, and cultural control variables are also included in the regressions, including mother's age at birth, the child's sex, type of birth, birth order, birth cohort (periods <1980, 1980-1989 and 19902000), mother's education, religion, ethnicity, area of residence, and the household standard of living. The variables for area of residence, living standards and mother's marital status can vary over time; the other variables are time-invariant.

Living standards are calculated from the characteristics of housing in which the mother reported living for at least three months: type of walls, roof, floor, type of lighting, primary source of drinking water, type of sanitary facilities, and type of fuel used for cooking food (see the Appendix for details). These variables are used to construct an index of household living standards using the principal component method. The first component explains a greater part of variance than the others and was used to define living standards for this study. This index is a non-monetary measure that is supposed to capture the socioeconomic status of the household (Filmer and Pritchett 2001; Montgomery et al. 2000).

Table 1 presents summary statistics for the independent variables for women in the data set. Note that the sample used for this study included 17,399 children, $49 \%$ of whom were girls. More than half of the children were born before 1990, and only $3 \%$ were from a multiple birth (e.g., twins). Approximately one child out of seven was born to a teenage mother ( $<19$ years). Consistent with the country's ethnic and demographic composition, the majority of mothers are of the Mossi ethnic group (48\%), Moslem (51\%), not educated (93\%) and of lower socioeconomic status (52\%).

Table 1: Summary statistics for the explanatory variables used in the regressions

\begin{tabular}{|c|c|c|}
\hline Variable & Number(weighted) & Per cent \\
\hline \multicolumn{3}{|l|}{ Marital status of the mother ${ }^{(n)}$} \\
\hline Married & $16,435.2$ & 94.5 \\
\hline Divorced & 426.7 & 2.4 \\
\hline Widowed & 537.1 & 3.1 \\
\hline \multicolumn{3}{|l|}{ Sex } \\
\hline Girl & $8,496.8$ & 48.8 \\
\hline Boy & $8,902.2$ & 51.2 \\
\hline \multicolumn{3}{|l|}{ Type of birth } \\
\hline Multiple & 506.7 & 2.9 \\
\hline Single & $16,892.3$ & 97.1 \\
\hline \multicolumn{3}{|l|}{ Birth order } \\
\hline 1st & $3,647.5$ & 21.0 \\
\hline $2-3$ & $5,762.2$ & 33.1 \\
\hline $4-5$ & $4,059.5$ & 23.3 \\
\hline 6 and + & $3,929.8$ & 22.6 \\
\hline
\end{tabular}


Table 1: (Continued)

\begin{tabular}{|c|c|c|}
\hline Variable & Number(weighted) & Per cent \\
\hline \multicolumn{3}{|l|}{ Period of birth } \\
\hline Before 1980 & $4,304.8$ & 24.7 \\
\hline $1980-1989$ & $5,331.8$ & 30.6 \\
\hline $1990-2000$ & $7,762.4$ & 44.6 \\
\hline \multicolumn{3}{|l|}{ Mother's age at birth } \\
\hline$<19$ years & $2,396.2$ & 13.8 \\
\hline $19-35$ years & $12,949.1$ & 74.4 \\
\hline 35 years and + & $2,053.7$ & 11.8 \\
\hline \multicolumn{3}{|l|}{ Mother's education } \\
\hline None & $16,110.0$ & 92.6 \\
\hline Primary education, secondary and + & $1,289.0$ & 7.4 \\
\hline \multicolumn{3}{|l|}{ Ethnicity of the mother } \\
\hline Mossi & $8,426.6$ & 48.4 \\
\hline Gourmantche & $1,271.8$ & 7.3 \\
\hline Peul & $1,246.7$ & 7.2 \\
\hline Gourounsi & $1,055.9$ & 6.1 \\
\hline Bobo-Bwa & 823.9 & 4.7 \\
\hline Lobi-Dagara & $1,268.7$ & 7.3 \\
\hline Others & $3,305.4$ & 19.0 \\
\hline \multicolumn{3}{|l|}{ Religion of the mother } \\
\hline Animist & $5,158.2$ & 29.6 \\
\hline Moslem & $8,919.2$ & 51.3 \\
\hline Christian & $3,274.8$ & 18.8 \\
\hline Others & 46.8 & 0.3 \\
\hline \multicolumn{3}{|l|}{ Area of residence $e^{(v)}$} \\
\hline Rural & $13,959.4$ & 80.2 \\
\hline Average city & $1,184.2$ & 6.8 \\
\hline Large city & $1,024.0$ & 5.9 \\
\hline Foreigner & $1,231.4$ & 7.1 \\
\hline \multicolumn{3}{|l|}{ Standard of living index ${ }^{(v)}$} \\
\hline Poor & $8,962.6$ & 51.5 \\
\hline Less poor & $2,630.5$ & 15.1 \\
\hline Relatively well off & $5,805.9$ & 33.4 \\
\hline $\mathbf{N}$ & $17,399.0$ & 100.0 \\
\hline
\end{tabular}

Note: (v): Variables whose value can change in the course of time (distribution at the end of observation, in the case of mortality).

\subsection{Limitations of the data}

Our data have some limitations, whose effects should not substantially alter the results. First, the survey did not collect information on children's educational trajectories and transitions to estimate the effect of divorce or widowhood on children's school performance. Second, our sample is selective because we could only interview women who survived and did not emigrate. The death or migration of a woman might have specific characteristics that could influence their children's mortality and education. In particular, given patrilocal residence, women who are newly divorced and do not feel 
supported in their marital community may leave, and they are more likely to be economically vulnerable (in other words, we selectively miss some of the most vulnerable among the divorced women; perhaps, this makes the results even stronger). Third, retrospective surveys are prone to inaccurate, incomplete or partial reporting of responses. For instance, deaths occurring immediately after living births might be underreported, and result in the underestimation of under-five mortality. Fourth, since data on children are collected from mothers in the survey, only information on women's own living standards can be used in the analysis - the housing conditions of children living apart from mothers was generally not available.

\section{Results}

\subsection{Descriptive analysis}

Kaplan-Meier curves are used to examine child survival and time until entry into school, respectively. The curves show the proportion of surviving children between the ages of 0 and 59 months (Figure 1) and the proportion who have not yet begun school from ages 5 to 10 years (Figure 2).

Both graphs show sizable differences for children by their mothers' marital situations. Differences are highly significant for both mortality $(\mathrm{p}<0.004)$ and entry into school $(\mathrm{p}<0.000)$. Divorce is negatively associated with child survival, an effect that is evident from birth, but becomes especially pronounced between the ages of 1 and 5 years. On the other hand, a father's death is not significantly related to child mortality, although, like divorce, it does reduce children's chances of entry into school. These results indicate that children of divorced and widowed mothers are generally disadvantaged in terms of their health and schooling prospects. 
Figure 1: Probability of child survival by marital status of the mother

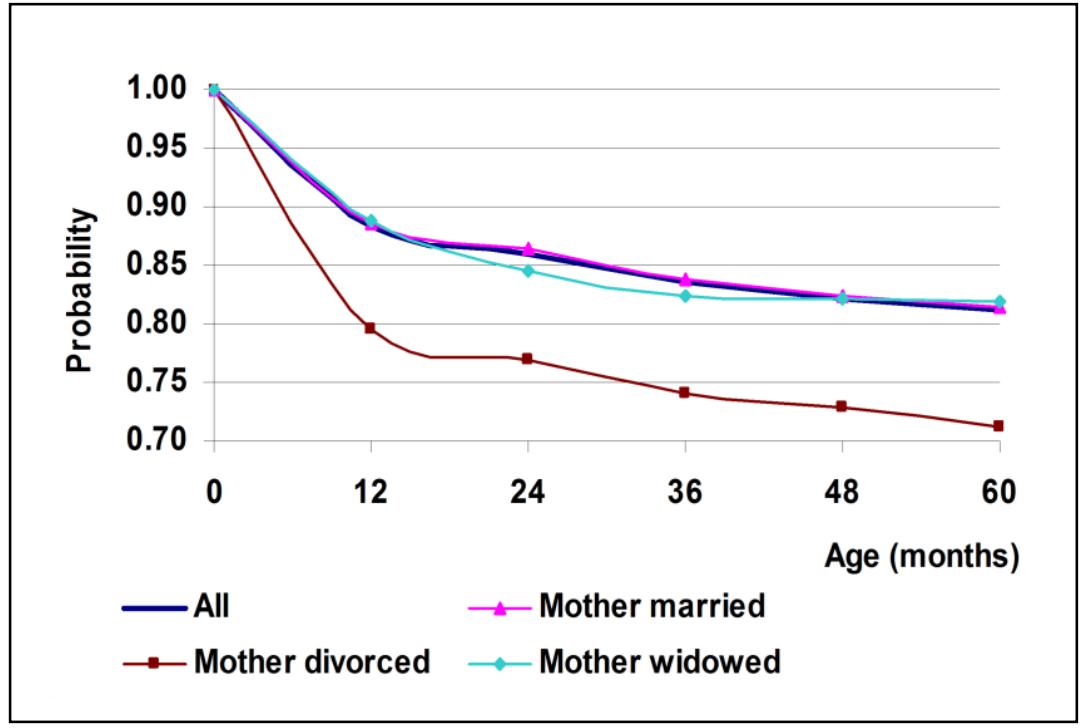

Figure 2: Probability of non-enrollment by marital status of the mother

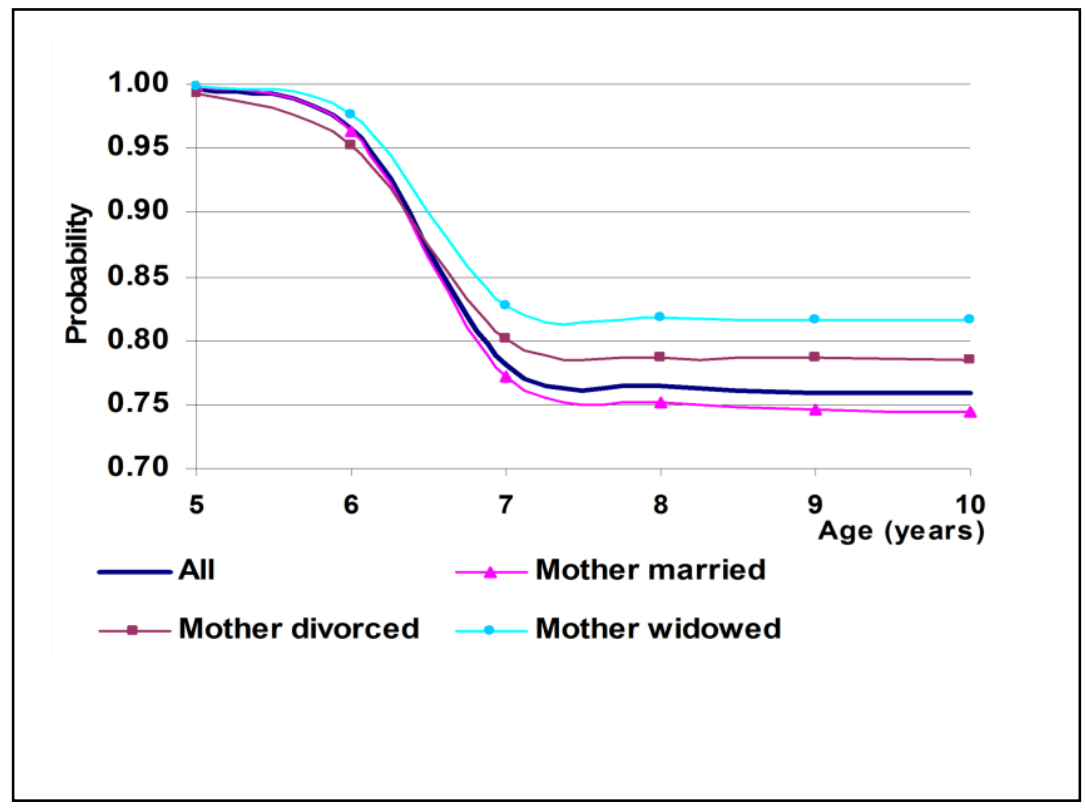




\subsection{Multivariate analysis}

Table 2 presents the results of the four piecewise exponential regression models. The table shows the estimated relative risks for each group compared to the reference category for each independent variable. The first two models analyze children's mortality under age 5 years, whereas models 3 and 4 examine the probability of entry into school between ages 5 to 10 years. In interpreting the results, we make use of information obtained from qualitative interviews conducted in urban and rural areas in 2006 and 2007. These data were collected through semi-structured interviews with 10 key informants working in nongovernmental organizations (NGOs), associations, and administrative services, and with 24 women who had experienced a divorce or widowhood. The aim of these interviews was to better understand the causes of divorce and the consequences of divorce and widowhood for the family and, in particular, on women and children. Details on qualitative interviews are reported elsewhere (Thiombiano 2009).

The regression results largely confirm the patterns seen in the Kaplan-Meier graphs. Indeed, the adverse consequences of divorce or widowhood on children's welfare appear to become somewhat more pronounced in models 2 and 4, when the broad set of covariates are introduced into the equations, and are more significant during the first two years following the union dissolution. The negative effect of union dissolution on children's welfare remains significant after controlling for other factors, and regardless of the household living standard. However, children living in wealthier households are more likely to be enrolled in school and less likely to experience early mortality than are other children, though the difference is not statistically significant.

Children of divorced parents experience higher estimated mortality risks under age 5 than those living with married mothers, an effect that is large and significant during the first two years after the divorce. The effect becomes statistically non-significant in subsequent years, probably reflecting a successful adjustment to the new situation by children and families. In the qualitative interviews, women also mentioned the negative effect of divorce on child health, with some mothers remarking on a decline in the health of their young children immediately after the divorce. "The children really suffered from the separation, they were hospitalized several times," said one urban woman. Divorce is also negatively associated with a child's schooling. The regression results indicate that children of divorced mothers have a significantly lower probability of entry into school than do children of intact families. This disadvantage is significant in the two years following parental divorce, but again disappears after two years.

In patrilineal societies like those of Burkina Faso, the child traditionally belongs to the father's family. In the event of divorce, the woman is often forced to give up custody of her children to the father. Of the 14 divorced women we interviewed, only two had custody of their children; the other children were in their father's custody or 
dispersed among several households. Yet the role of the mother in childcare and education remains fundamental. Children separated from their mothers may not receive suitable care (food, medical care, etc.), which could compromise their health. Regarding schooling, in addition to children's lower likelihood of enrollment, in the qualitative interviews, women described cases of school leaving and grade repetition. "When the first child repeated sixth grade, the father said he could not pay for the schooling of a child who repeats a year. So the child quit school and became a tapestry-maker because I do not have the money to pay for his school. He did the same thing with my daughter as well," said an urban woman.

As expected, a father's death greatly reduces the chances of a child's schooling compared to children whose parents are both alive and married. Their relative chances of school enrollment falls by $63 \%$ during the two first years after father's death, and this decrease remains important even in subsequent years (by 36\%). The negative effect of father's death can be mitigated when children receive substantial support from other members of the family. Kobiané et al. (2005) point out that orphans are more likely to be schooled when they receive substantial support from kin - older brothers and sisters, uncles, aunts, and others - than when they are solely in their mother's care. In principle, in patrilineal societies the father's family has the social obligation to provide assistance to orphans including children whose mother remains alive. Nevertheless, according to the widows we interviewed, this family solidarity is far from guaranteed these days. Some of these widows stated that their in-laws do not provide economic support to the children of their deceased relative; indeed, they may even go so far as to dispossess the mother of wealth received from her late husband or his kin, including household goods.

As noted in the descriptive results, the father's death is not significantly associated with the risk of child mortality. Similar results were observed in Gambian rural areas, where having a living father was not found to significantly affect child survival (Sear et al. 2002). This result may perhaps be grounded in the gender-based division of roles within the household. Because the education and care of young children are mainly provided by the mother, the father's death is somewhat less critical for these outcomes if they continue to live with their mother. Nevertheless, economic constraints may cause these children to have poorer access to healthcare, as indicated by a widow speaking about the consequences of her husband's death: "Once when my child was sick, I left to go to Saint-Camille (medical centre of the Catholic mission, not too expensive). I did not have money to pay the consultation fees. I went with my shivering child to the office of a caregiver Father [religious]... Out of compassion, he treated my child". This is certainly not an isolated case, and some children of deceased fathers certainly do not have access to adequate health care.

Many of the control variables also appear to affect children's welfare in terms of survival and first school enrolment, and we briefly comment on those results below. Of 
the bio-demographic factors, multiple birth, children born before 1980, and those of teenage mothers face significantly higher risks of dying before age 5 than others. These results are similar to those from other studies on child mortality in Africa (e.g., Cleland et al. 1992; Hobcraft et al. 1984). The higher risk of mortality among children born before 1980, compared to those born after 1990, can be explained by the overall decline in mortality in sub-Saharan African countries since then (Cleland et al. 1992; Hill and Pebley 1989; Rutstein 2000) and by improvements in the Burkina healthcare system. The severe drought of 1973-1974 also had harmful effects on the health of children of the earlier generation (Garenne and Gakusi 2006). However, contrary to reports from other studies (Hobcraft et al. 1985; Lalou and LeGrand 1997), our results do not show a significant effect of gender and birth order on infant and child mortality. Children of the two earlier generations also are seen to have a lower likelihood of school enrollment than to those born after 1990, presumably due to significant expansion of the educational system and a growing demand for schooling in recent years. But, as has been observed in other African countries, Burkinabè girls remain less likely to be educated than do boys.

Socioeconomic and cultural factors are also found to be associated with child mortality and schooling. Children of educated mothers have a better chance of entering school than do others, but, as has occasionally been found by other studies on the Sahel (Lalou and LeGrand 1997) maternal education is not found to significantly alter the risk of dying. Rural children also have a greater risk of mortality under age 5 and a lower likelihood of entering school than do residents of cities.

Contrary to evidence from urban Burkina Faso (Dos Santos and LeGrand 2007), cultural factors such as ethnic affiliation and religion have no significant impact on child mortality at the national level, nor, according to Becher et al. (2004) in rural parts of the country. The mother's ethnic affiliation and religion do, however, give rise to significant differences in schooling. Children of Gourmantche, Peul, and Lobi-Dagara mothers seem to be less likely to enter school than are those of Mossi mothers - the dominant ethnic group in the country. On the other hand, children of Gourounsi and Bobo-Bwa women appear to be especially advantaged in regard to access to schooling. Children born to Christian mothers also have better chances of schooling than do those of Moslem women. On the whole, these results are similar to those found by other research on the determinants of child schooling in Burkina Faso (Kobiané 2006).

Finally, the estimated baseline risks of mortality under age 5 years and school enrolment vary systematically across age groups. As expected, the instantaneous risk of dying is considerably higher during the neonatal period, compared to older ages, even after controlling for other factors. The probability of a child entering school is highest at ages of 7 and 8 years, compared to both younger and older ages. 
Gnoumou Thiombiano et al: : Effects of parental union dissolution on child mortality in Burkina Faso

Table 2: $\quad$ Relative mortality risk under age 5 and entry into school (results of piecewise exponential models)

\begin{tabular}{|c|c|c|c|c|}
\hline \multirow[b]{2}{*}{ Variable } & \multicolumn{2}{|c|}{ Mortality } & \multicolumn{2}{|c|}{ Entry into school } \\
\hline & Model 1 & Model 2 & Model 3 & Model 4 \\
\hline \multicolumn{5}{|c|}{ Marital status of the mother ${ }^{(v)}$} \\
\hline Married & Reference & Reference & Reference & Reference \\
\hline Divorce $<2$ years & $1.36^{*}$ & $1.43^{*}$ & 0.86 & $0.60^{*}$ \\
\hline Divorce 2 year + & 0,57 & 0.67 & 1.96 & 1.66 \\
\hline Widowed $<2$ years & 1.07 & 1.25 & $0.44^{*}$ & $0.37^{\star \star}$ \\
\hline Widowed 2 year + & 0.71 & 0.70 & 0.74 & $0.64^{*}$ \\
\hline \multicolumn{5}{|l|}{ Sex } \\
\hline Male & & Reference & & Reference \\
\hline Female & & 0.91 & & $0.65^{* \star *}$ \\
\hline \multicolumn{5}{|l|}{ Type of birth } \\
\hline Single & & Reference & & Reference \\
\hline Multiple & & $2.70^{\star \star \star}$ & & 0.88 \\
\hline \multicolumn{5}{|l|}{ Birth order } \\
\hline $4-5$ & & Reference & & Reference \\
\hline 1st & & 0.95 & & 1.05 \\
\hline $2-3$ & & 0.93 & & 0.99 \\
\hline 6 and + & & 1.12 & & 1.04 \\
\hline \multicolumn{5}{|l|}{ Period of birth } \\
\hline Before 1980 & & $1.26^{* *}$ & & $0.69^{* \star \star}$ \\
\hline $1980-1989$ & & 1.01 & & $0.87^{\star}$ \\
\hline $1990-2000$ & & Reference & & Reference \\
\hline \multicolumn{5}{|l|}{ Mother age at birth } \\
\hline $19-35$ & & Reference & & Reference \\
\hline$<19$ years & & $1.47^{\star \star \star}$ & & 0.95 \\
\hline 35 years and + & & 0.87 & & 0.98 \\
\hline \multicolumn{5}{|l|}{ Mother's education } \\
\hline None & & 1.19 & & $0.52^{\star \star \star}$ \\
\hline Primary education \& + & & Reference & & Reference \\
\hline \multicolumn{5}{|l|}{ Ethnicity of the mother } \\
\hline Mossi & & Reference & & Reference \\
\hline Gourmantche & & 1.12 & & $0.46^{\star \star \star}$ \\
\hline Peul & & 0.88 & & $0.49^{* * *}$ \\
\hline Gourounsi & & 1.09 & & $1.36^{*}$ \\
\hline Bobo-Bwa & & 0.98 & & $1.31^{*}$ \\
\hline Lobi-Dagara & & 0.90 & & $0.56^{* \star}$ \\
\hline Others & & 0.94 & & 0.97 \\
\hline \multicolumn{5}{|l|}{ Religion of the mother } \\
\hline Moslem & & Reference & & Reference \\
\hline Animist & & 0.94 & & 0.86 \\
\hline Christian & & 0.94 & & $1.67^{* \star \star}$ \\
\hline Others & & 0.62 & & 2.05 \\
\hline \multicolumn{5}{|l|}{ Area of residence ${ }^{(v)}$} \\
\hline Large city & & Reference & & Reference \\
\hline Rural & & $1.82^{* * \star}$ & & $0.23^{\star \star \star}$ \\
\hline Average-sized city & & $1.54^{\star \star}$ & & $0.61^{* \star \star}$ \\
\hline Foreigner & & 1.15 & & $0.39^{* \star \star}$ \\
\hline \multicolumn{5}{|l|}{ Living Standard index ${ }^{(v)}$} \\
\hline Poor & & 1.18 & & $0.49^{* * \star}$ \\
\hline Medium class & & 1.20 & & $0.74^{\star \star}$ \\
\hline Rich & & Reference & & Reference \\
\hline
\end{tabular}


Table 2: (Continued)

\begin{tabular}{lcccc}
\hline Variable & \multicolumn{2}{c}{ Mortality } & \multicolumn{2}{c}{ Entry into school } \\
Model 1 & Model 2 & Model 3 & Model 4 \\
\hline Baseline risk & Model & & & \\
-1 month & $0.049^{* * *}$ & $0.020^{* * *}$ & & \\
$1-12$ months & $0.007^{* * *}$ & $0.003^{* * *}$ & & \\
$13-59$ months & $0.002^{* * *}$ & $0.001^{* * *}$ & & $0.059^{* * *}$ \\
Under age 7 & & & $0.006^{* * *}$ & $1.598^{* * *}$ \\
$7-8$ years & & & $0.119^{* * *}$ & $0.064^{* * *}$ \\
8 to 10 years & & & $0.004^{* * *}$ & \\
\hline
\end{tabular}

Note: ${ }^{\star \star *} p<0.001 ;{ }^{* \star} p<0.01 ;{ }^{*} p<0.05$. (v): Variable whose value can change over time.

\section{Discussion}

This study examined the effects of parental union dissolution - divorce or a father's death - on child mortality and schooling in Burkina Faso, using data from a detailed national retrospective family-life survey. The results indicate that the family context plays an important role in determining two important aspects of children's welfare: their probabilities of dying before age 5 and of entering school. A recent divorce is associated with both a higher child mortality risk and also with a lower probability of entering school. The effect on mortality disappears for children whose mothers have been divorced for more than two years. For school entry, the effect of divorce persists even after two years, albeit at a reduced magnitude. In patrilineal and virilocal societies such as Burkina Faso, children are generally perceived to belong to their father's family. When a couple divorces, the residence being virilocal, the woman typically moves out leaving her children behind, sometimes at a young age, in the care of the father. Even though Burkina Faso law - the Code on the Individual and the Family (article 402, Burkina Faso, 1990) - stipulates that children under age 7 must preferably be entrusted to their mother's care, this provision is seldom applied. Separated from their mother, children are more likely to be deprived of affection, good nutrition, and suitable healthcare.

Other studies on West Africa have similarly reported that children who are not cared for by their mothers can face health and schooling disadvantages. In the context of rural Mali, for example, Hill and Randall (1984) explain the higher mortality risk of Tamasheq children in comparison to Bella (former slaves in the ethnic group) children by the conditions of childcare. Bella children are cared for by their mothers, whereas Tamasheq women of high social standing (noble class) generally entrust childcare to young Bella slaves (Hilderbrand et al. 1985; Hill and Randall 1984). Studies on the practice of "fostering" children in Africa also show that the fostered children, who often are children of divorced parents, tend to have poorer nutritional status than do those 
living with their biological mother, and are generally less well looked after (Bledsoe et al. 1988; Roger-Petitjean 1999; Vandermeersch and Chimere-Dan 2002). These children are at times brutally separated from their mothers and entrusted to relatives who may only accommodate them because of social obligation, which explains their poor conditions (Roger-Petitjean 1999; Vandermeersch and Chimere-Dan 2002). Even children under the mother's custody after divorce can be deprived of adequate healthcare and good nutrition, simply because households headed by divorced women are often poorer and less able to afford food and medical care (Bledsoe et al. 1988). Moreover, as one key informant (lawyer, member of an association) explained in an interview with the main author in Burkina Faso, in cases of highly conflictual divorces, the fathers sometimes vindictively refuse to fulfill their childcare responsibilities.

The results also show that children with deceased fathers have a lower probability of schooling than do those living in intact families. To some extent, this finding might be caused by the high tendency of orphans to be fostered (Case et al. 2004) and by the strong likelihood of their living in poorer households (Ainsworth and Filmer 2002; Lloyd and Blanc 1996). The father is often the main provider of household resources, and social norms in much of Africa impose a heavy responsibility on him of funding his children's education (Lloyd and Gage-Brandon 1994).

The results of the study confirm our initial hypotheses, namely, that parental union dissolution is linked to relatively high child mortality risks and low probabilities of entering school. The regression results are also supported by the testimony of divorced or widowed women and of key informants interviewed in the qualitative survey. It is worth noting that, despite considerable efforts made by the government in recent years to expand the schooling system, the gross enrollment ratio for primary school in Burkina Faso was only 79 in 2011 (UNESCO 2012) - one of the very lowest in the world. Similarly, the under-5 mortality rate in the country was estimated to be 167 per thousand in 2005-10 (UN Population Division 2012) - among the highest in the world. Improving children's health and their schooling prospects is clearly of immense importance for their future and for that of their country, and higher risk should receive particular attention in these efforts. This study has shown that children of divorced parents or a deceased father tend to be in especially precarious situations, and their special needs should be taken into account in policies and interventions aiming to improve child health and schooling prospects. 


\section{References}

Ainsworth, M. and Filmer, D. (2002). Poverty, AIDS, and children's schooling: A targeting dilemma. Washington: World Bank (World Bank Policy Research Working Paper No. 2885).

Alam, N., Saha, S.K., Razzaque, A., and Van Ginneken, J.K. (2001). The effect of divorce on infant mortality in remote area of Bangladesh. Journal of Biosocial Science 33(2): 271-278. doi:10.1017/S0021932001002711.

Becher, H., Müller, O., Jahn, A., Gbangou, A., Kynast-Wolf, G., and Kouyaté, B. (2004). Risk factors of infant and child mortality in rural Burkina Faso. Bulletin of the World Health Organization 82: 265-273.

Bennett, T., Braverman, P., Egerter, S., and Kiely, J.L. (1994). Maternal marital status as a risk factor for infant mortality. Family Planning Perspectives 26(6): 252271. doi:10.2307/2135890.

Bhuiya, A. and Chowdhury, M. (1997). The effect of divorce on child survival in a rural area of Bangladesh. Population Studies 51(1): 57-61. doi:10.1080/0032472 031000149726.

Bledsoe, C.H., Ewbank, D.C., and Isiugo-Abanike, U.C. (1988). The effect of child fostering on feeding practices and access to health service in rural Sierra Leone. Social Science \& Medicine 27 (6): 627-636. doi:10.1016/0277-9536(88)900111 .

Blossfeld, H.-P., Golsch, K., and Rohwer, G. (2007). Event history analysis with Stata. Mahwah, NJ: Lawrence Erlbaum.

Blossfeld, H.-P. and Rohwer, G. (2002). Techniques of event history modeling. New approaches to causal analysis (2nd ed.). Hillsdale, NJ: Lawrence Erlbaum.

Burkina Faso (1990). Code des personnes et de la famille. Ouagadougou: Government of Burkina Faso.

Case, A., Paxson, C., and Ableidinger, J. (2004). Orphans in Africa: Parental death, poverty, and school enrollment. Demography 41(3): 483-508. doi:10.1353/ dem.2004.0019.

Cleland, J., Bicego, G., and Fegan, G. (1992). Socioeconomic inequalities in childhood mortality: The 1970s to the 1980s. Health Transition Review 2(1): 1-18.

Dos Santos, S. and LeGrand, T.K. (2007). Accès à l'eau et mortalité des enfants à Ouagadougou (Burkina Faso). Environnement, Risques\&Santé 6(5): 365-371. 
Filmer, D. and Pritchett, L.H. (2001). Estimating wealth effects without expenditure data - or tears: An application to educational enrollments in states of India. Demography 38(1): 115-132. doi:10.1353/dem.2001.0003.

Foster, A.K. (2002). Polygyny and child survival in West Africa. Social Biology 49(12): $74-89$.

Freedman, D., Thornton, A., Camburn, D., Alwin, D., and Young-DeMarco, L. (1988). The life history calendar: A technique for collecting retrospective data. In: Clogg, C.C. (ed.). Sociological Methodology 18. San Francisco: Jossey-Bass publishers: 37-68. doi:10.2307/271044.

Garenne, M. and Gakusi, E. (2006). Health transitions in sub-Saharan Africa: Overview of mortality trends in children under 5 years old (1959-2000). Bulletin of the World Health Organization 84: 470-478. doi:10.2471/BLT.05.029231.

Hilderbrand, K., Hill, A.G., Randall, S., and van den Eerenbeemt, M.L. (1985). Child mortality and care of children in rural Mali. In: Hill, A.G. (ed.). Population, health and nutrition in the Sahel: Issues in the welfare of selected West African communities. London, UK: Routledge and Kegan Paul: 184-206.

Hill, A. and Randall, S. (1984). Différences géographiques et sociales dans la mortalité infantile et juvénile au Mali. Population 6: 921-946. doi:10.2307/1533041.

Hill, K. and Pebley, A.R. (1989). Child mortality in the developing world. Population and Development Review 15(4): 657-688. doi:10.2307/1972594.

Hobcraft, J.N., McDonald, J.W., and Rutstein, S.O. (1984). Socio-economic factors in infant and child mortality: A cross-national comparison. Population Studies 38(2): 193-223. doi:10.2307/2174073.

Hobcraft, J.N., McDonald, J.W., and Rutstein, S.O. (1985). Demographic determinants of infant and early child mortality: A comparative analysis. Population Studies 39(3): 363-385. doi:10.1080/0032472031000141576.

Isaac, B.L. and Feinberg, W.E. (1982). Marital form and infant survival among the Mende of rural Upper Bambara Chiefdom, Sierra Leone. Human Biology 54: 627-634.

Kobiané, J.-F. (2006). Ménages et scolarisation des enfants au Burkina Faso : À la recherche des déterminants de la demande scolaire. Louvain-la-Neuve, Belgium: Academia-Bruylant. 
Kobiané, J.-F., Calves, A.-E., and Marcoux, R. (2005). Parental death and children's schooling in Burkina Faso. Comparative Education Review 49(4): 468-489. doi:10.1086/491592.

Lalou, R. and LeGrand, T. (1997). Child mortality in the urban and rural Sahel. Population: An English Selection 9: 147-168.

Lesthaeghe, R., Kaufmann, G., and Meekers, D. (1989). The Nuptiality Regime in SubSaharan Africa. In: Lesthaeghe, R. (ed.). Reproduction and social organization in Sub-Saharan Africa. University of California Press: 238-237.

Lloyd, B.C. and Blanc, A.K. (1996). Children's schooling in sub-Saharan Africa: The role of fathers, mothers and others. Population and Development Review 22(2): 265-298. doi:10.2307/2137435.

Lloyd, B.C. and Gage-Brandon, A. (1994). High fertility and children's schooling in Ghana: Sex differences in parental contributions and educational outcomes. Population Studies 48(2): 293-306. doi:10.1080/0032472031000147806.

Mauldon, J. (1990). The effect of marital disruption on children's health. Demography 27(3): 431-446. doi:10.2307/2061377.

Montgomery, M.R., Gragnolati, M., Burke, K.A., and Paredes, E. (2000). Measuring living standards with proxy variables. Demography 37(2): 155-174. doi: $10.2307 / 2648118$.

Panel Study of Income Dynamics (2012). PSID Calendar Methods Study [electronic resource].

[http://psidonline.isr.umich.edu/Data/documentation/ehc/PSIDcalendarMethods Study.html].

Poirier, J., Piché, V., Le Jeune, G., Dabiré, B., and Wane, H.R. (2001). Projet d'étude des stratégies de reproduction des populations sahéliennes à partir de l'enquête 'Dynamique migratoire, insertion urbaine et environnement au Burkina Faso'. Cahiers québécois de démographie 30(2): 289-309. doi:10.7202/010312ar.

Roger-Petitjean, M. (1999). Accès aux soins des enfants confiés en milieu urbain africain. Le cas de Bobo Dioulasso. In: Adjamagbo, A., Guillaume, A., and Koffi, N. (eds.). Santé de la mère et de l'enfant : Exemples africains. Montpellier: IRD: 17-36.

Rutstein, S. (2000). Factors associated with trends in infant and child mortality in developing countries during the 1990s. Bulletin of the World Health Organization 78(10): 1256-1270. 
Sear, R., Steele, F., Mcgregor, I.A., and Mace, R. (2002). The effects of kin on child mortality in rural Gambia. Demography 39(1): 43-63. doi:10.1353/dem. 2002.0010.

Thiombiano, B. (2009). Ruptures d'unions conjugales au Burkina Faso: Causes et effets sur les femmes et leurs enfants. [Ph.D. Thesis]. Université de Montréal.

UNESCO (2012). Table 5. Enrollment ratios by ISCED level. [electronic resource]. [http://stats.uis.unesco.org/unesco/TableViewer/tableView.aspx?ReportId=182].

UN Population Division (2012). World Population Prospects: Detailed data. [electronic resource]. [http://esa.un.org/unpd/wpp/unpp/panel_indicators.htm].

Vandermeersch, C. and Chimere-Dan, O. (2002). Child fostering under six in Senegal in 1992-1993. Population 57(4-5): 659-685. doi:10.2307/3246661. 


\section{Appendix}

\section{Table A-1: Variables used in constructing the index of living standards}

\begin{tabular}{|c|c|c|}
\hline Variable & Number (weighted) & Percent \\
\hline \multicolumn{3}{|l|}{ Wall materials } \\
\hline Cement & 193.0 & 5.0 \\
\hline Stones & 14.5 & 0.4 \\
\hline Clay & 3404.9 & 88.0 \\
\hline Others & 258.6 & 6.7 \\
\hline \multicolumn{3}{|l|}{ Roof materials } \\
\hline Concrete and tile & 2.1 & 0.1 \\
\hline Metal sheet with ceiling & 57.2 & 1.5 \\
\hline Metal sheet without ceiling & 823.2 & 21.3 \\
\hline Clay & 1415.3 & 36.6 \\
\hline Others & 1573.2 & 40.6 \\
\hline \multicolumn{3}{|l|}{ Soil materials } \\
\hline Marble & 4.7 & 0.1 \\
\hline Tiles & 21.4 & 0.6 \\
\hline Cement & 718.3 & 18.6 \\
\hline Earth & 3126.7 & 80.8 \\
\hline \multicolumn{3}{|l|}{ Lighting mode } \\
\hline Electricity and gas & 138.0 & 3.6 \\
\hline Oil & 2770.8 & 71.6 \\
\hline Others & 962.2 & 24.8 \\
\hline \multicolumn{3}{|l|}{ Energy for cooking } \\
\hline Electricity and gas & 39.2 & 1.0 \\
\hline Oil & 15.8 & 0.4 \\
\hline Coal & 25.5 & 0.7 \\
\hline Wood & 3759.3 & 97.1 \\
\hline Others & 31.3 & 0.8 \\
\hline \multicolumn{3}{|l|}{ Source of drinking water } \\
\hline Running water & 91.2 & 2.4 \\
\hline Fountain & 979.6 & 25.3 \\
\hline Well & 2374.4 & 61.3 \\
\hline Others & 425.8 & 11.0 \\
\hline \multicolumn{3}{|l|}{ Type of sanitary convenience } \\
\hline Toilet & 28.2 & 0.7 \\
\hline Latrine & 706.1 & 18.2 \\
\hline Others & 3136.8 & 81.0 \\
\hline $\mathbf{N}$ & 3871.0 & 100.0 \\
\hline
\end{tabular}

Note: Housing tenure, often included when calculating the index of living standards, has not been considered. In the context of Burkina Faso, it appears to be inappropriate for measuring the standard of living of households because those in urban unzoned areas (precarious housing) and those in villages usually declare themselves to be home owners. 
Gnoumou Thiombiano et al: : Effects of parental union dissolution on child mortality in Burkina Faso 